\title{
Article
}

\section{Using Adaptive Capacity to Shift Absorptive Capacity: A Framework of Water Reallocation in Highly Modified Rivers}

\author{
Peter M. Rudberg ${ }^{1,2}$ (D) and Timos Karpouzoglou ${ }^{3, *(\mathbb{D}}$ \\ 1 GeoViable, 14940 Córdoba, Spain; peter.rudberg@geoviable.org \\ 2 Stockholm Environment Institute, 11523 Stockholm, Sweden \\ 3 Division of History of Science, Technology and Environment, KTH Royal Institute of Technology, \\ 10044 Stockholm, Sweden \\ * Correspondence: timothy.karpouzoglou@abe.kth.se
}

Citation: Rudberg, P.M. Karpouzoglou, T. Using Adaptive Capacity to Shift Absorptive Capacity: A Framework of Water Reallocation in Highly Modified Rivers. Water 2022, 14, 193. https://doi.org/10.3390/w14020193 Academic Editors: Chin $\mathrm{H}$ Wu and Rui Cunha Marques

Received: 27 September 2021 Accepted: 13 December 2021 Published: 11 January 2022

Publisher's Note: MDPI stays neutral with regard to jurisdictional claims in published maps and institutional affiliations.

Copyright: (C) 2022 by the authors. Licensee MDPI, Basel, Switzerland. This article is an open access article distributed under the terms and conditions of the Creative Commons Attribution (CC BY) license (https:// creativecommons.org/licenses/by/ $4.0 /)$.
Abstract: Damming and water regulation creates highly modified rivers with limited ecosystem integrity and resilience. This, coupled with an ongoing global biodiversity crisis, makes river restoration a priority, which requires water reallocation. Coupled human-natural systems research provides a suitable lens for integrated systems' analysis but offers limited insight into the governance processes of water reallocation. Therefore, we propose an analytical framework, which combines insight from social-hydrological resilience and water reallocation research, and identifies the adaptive capacity in highly modified rivers as the capacity for water reallocation. We test the framework by conducting an analysis of Sweden, pre- and post-2019, a critical juncture in the governance of the country's hydropower producing rivers. We identify a relative increase in adaptive capacity post2019 since water reallocation is set to occur in smaller rivers and tributaries, while leaving large-scaled rivers to enjoy limited water reallocation, or even increased allocation to hydropower. We contend that the proposed framework is broad enough to be of general interest, yet sufficiently specific to contribute to the construction of middle-range theories, which could further our understanding of why and how governance processes function, change, and lead to outcomes in terms of modified natural resource management and resilience shifts.

Keywords: social-hydrological resilience; water resilience; socio-hydrology; adaptive governance; hydropower; riverine ecosystem; electric system; Sweden

\section{Introduction}

Dams, and their resulting water regulation, represent one of the most significant human modifications of the biosphere [1]. Damming and water regulation creates highly modified rivers, as water is allocated to human use, including industrial and urban water requirements, irrigation, hydropower production, shipping, and mining [2]. The required engineering works and water abstraction negatively impact river connectivity-i.e., the movement and exchange of water, energy, material, and species within the river system and surrounding landscapes - compared to free flowing rivers [3,4]. The most significant global driver of river connectivity loss is the up- and downstream propagation of fragmentation and artificial flow regulation, caused by the construction and functioning of dams [2].

Reduction in river connectivity negatively impacts riverine ecosystem integrity and biodiversity [4-7], which in turn impacts ecosystem resilience [8-11]. Riverine biodiversity loss is currently occurring on alarming scale and rate [5], which suggests a significant loss of riverine ecosystem resilience. In order to halt biodiversity loss, the safeguarding and restoration of freshwater connectivity is a top political priority that requires significant measures, such as limiting the construction of new dams, implementing environmental flow in existing dams, and removing dams [12-14]. The last two options require a reallocation of water from one type of actor and use to another [15-17]. 
Water reallocation is a societal challenge that involves difficult political, policy, and regulatory tradeoffs, because the initial water allocation can provide significant benefits to society. For example, the Lule River in Sweden is a highly modified river, which generates $10 \%$ of Sweden's total electricity demand through hydropower production [18]. Significant reallocation of water in the Lule River, to increase river connectivity, would decrease both electricity generation and balancing capacity, which could affect the electrical system negatively [19]. Thus, water reallocation requires a careful exploration of the tradeoffs and uncertainties that arise across hydrological, ecological, and societal systems and processes.

Social-hydrological resilience (SHR) provides a suitable lens for such integrated hydrological, ecological, and societal systems' analysis. SHR research forms part of an expanding field of research into coupled human-natural systems, with its principal focus on water systems, including research into water resilience [20,21] and socio-hydrology [22-24]. In this paper, we draw on the concept of SHR, by focusing on two resilience capacities: absorptive and adaptive capacity, which have been previously formulated in the literature [23].

The modeling and analysis of human-natural systems can provide significant insights into the tradeoffs and uncertainties of water reallocation [22,25-28]. However, the majority of modeling research lacks any clear relationship - or even critical reflection on-how the insight gained from modeling influences the governance and decision-making processes of water reallocation [29]. Existing water rights can be virtually impossible to modify if they go against the wishes of the rights' owners [30]. This means that, even in cases where more equitable, efficient, and resilient outcomes can be identified, there is a range of barriers, which can prevent societally desirable water reallocation from occurring [31,32]. We therefore hypothesize that research into highly modified rivers will benefit by combining SHR and water reallocation research in a new analytical framework.

A framework combining insight from these two research fields is a useful innovation since it focuses attention on hydrological and ecosystem processes in river basins but also provides the tools and understanding to analyze the social processes, with distinct actor interests and institutional settings, that play out and shape the shifts in resilience in those basins [24].

In this paper, we give a brief overview of the research into social-hydrological resilience and water reallocation which we combine into an analytical framework in order to analyze highly modified river basins. We test the framework by analyzing recent legislative and policy developments related to river restoration and hydropower production in Sweden, the EU's most significant hydropower-producing member state [33]. We believe that our approach and framework is appropriate for analyzing highly modified river basins, where there is a societal preference for restoring riverine ecosystem integrity and resilience through increasing river connectivity.

\section{Theoretical Foundation for the Framework}

\subsection{Social-Hydrological Resilience}

We understand social-hydrological systems' research to form part of the broader literature on coupled human-natural systems, which are focused on water and the hydrological cycle [20,22]. Earlier work on coupled human-natural systems explored resilience in terms of absorptive, adaptive, and transformative capacities [23]. However, most of this work featured a normative stance regarding how to achieve the desired goals of system functioning and change [20,34]. The field has been criticized as having a functionalist, simplistic logic of governance, focusing on how it ought to change, which does little to further our understanding of why and how governance works and evolves [35,36].

In this paper, we employ a more analytical stance. We identify two resilience capacities - absorptive and adaptive - as being of particular importance for understanding the options and tradeoffs that face those who are responsible for the governance of highly modified river basins. Absorptive capacity refers to the underlying ability of a system to absorb disturbance, while retaining its essential structures and stability [37]. Adaptive capacity, or adaptability, was defined earlier; as "the capacity of actors in a system to influ- 
ence resilience" [34]. In order to distinguish between absorptive and adaptive capacities, as two separate resilience functions, we define adaptive capacity as the ability of actors to adjust functions and processes that modify a system's underlying absorptive capacity.

In the literature on resilience and coupled human-natural systems, adaptive capacity has been increasingly fused with the concept of adaptive governance [38]. In adaptive governance literature, adaptive capacity tends to be emphasized as a desired goal of governance and is influenced by politics, policy, and the law, as well as other processes; such as collaboration, knowledge, and learning [39-43]. However, the literature on adaptive governance offers limited guidance on how to understand and influence complicated and contextually-dependent, real-life governance situations [44]. Searches for, and evidence of, links between key adaptive governance processes, such as social learning, and modifications in natural resource management and resilience are also sparse [45,46].

In this paper, we establish a clear link between governance processes and modifications to natural resource use by identifying the capacity for water reallocation as adaptive capacity related to highly modified river systems. Water reallocation is a concrete management option in a river that potentially modifies the absorptive capacity of the different sub-systems in the river basin. Our exploration focuses on the riverine ecosystem and electric system that are sub-systems in, and connected to, rivers that have been heavily modified by hydropower production.

The absorptive capacity of an electric system can be understood as its capacity to sustain a power balance over all timescales, by resisting and recovering (in a timely manner) from low-impact, high-probability events and high-impact, low-probability events [47,48]. Large-scale dam hydropower increases the absorptive capacity of the electric system because of its high flexibility, which comes from cost-effective and efficient frequency control, energy storage, and black start and island running capacities [49].

The absorptive capacity of the riverine ecosystem can be understood as the ecosystem's inherent ability to maintain its characteristic patterns and rates of processes, in response to disturbances, including the inherent variability of its climate regimes [11] as well as to climate change effects [50]. Although some critics have called it a simplification [25,51], the available evidence indicates that a robust connection exists between river connectivity and riverine ecosystem integrity $[4,6,52]$. Ecosystem integrity can in turn be used as a proxy for the riverine ecosystem's absorptive capacity [8,9]. Thus, hydropower production decreases the absorptive capacity of the riverine ecosystem because of decreased river connectivity, which is caused by the fragmentation and artificial flows that come from the construction and functioning of dams $[2,4,6,11]$.

\subsection{Governance Challenges of Water Reallocation}

Water reallocation concerns the redistribution of water, claimed for other purposes; such as irrigation or hydropower production [16]. Water reallocation can be divided into two forms: non-voluntary and voluntary [53]. In non-voluntary reallocation, the original water-user is forced to give up part or all of the water against their will, through administrative reallocation [54], or unilateral water diversions in transnational river basins. In voluntary reallocation the water-user is persuaded to give up their usage and right to water, through negotiation or monetary means.

Water reallocation research often involves case studies, which focus on real-life challenges of reallocating water between different users. The research has identified various barriers to water reallocation that include sociocultural, scientific, infrastructural, and governance challenges $[16,31,55]$. As our focus is on governance, we distilled the range of identified, governance variables in the literature into three key challenges. These will be briefly elaborated in this section. They are (1) gaining an overview of existing water use and rights, (2) creating and maintaining cost effective and flexible mechanisms for water reallocation, and (3) monitoring and enforcing compliance of water use in accordance with granted rights. 
Gaining an overview of existing water use and rights is an initial requirement for water reallocation [16]. In many countries, water is a public resource, but a range of actors can possess water rights; such as, concessions and more informal rights that emerge from practice [55]. Contested and unclear initial water allocation in a basin can significantly hamper any efforts towards water reallocation [56].

Overarching goals of water reallocation can be identified as to create and maintain cost effective and flexible mechanisms [16,57]. Cost effectiveness is determined by the number and variety of resources, required to facilitate desirable water reallocation; i.e., the transaction costs that arise from the modification of water rights [31]. Flexibility refers to the ability to reallocate water in line with changing societal preferences [58], and to adjust to the inherent uncertainties in the hydrological and climatic developments that affect the water resources, as well as riverine ecosystem response [43].

It is also vitally important to monitor and enforce compliance of water use, in accordance with the granted rights, given that an estimated $30-50 \%$ of global water supply is stolen [59]. However, the monitoring required, to ensure abidance to established water rights and to detect unauthorized use, is significant and can require capacities and infrastructure that are not always sufficiently developed, even in industrialized nations [60]. Thus, even the best planned and most cost-effective water reallocation system can be undermined, by water theft, if insufficient monitoring exists and if no dissuasive penal systems are in place.

The governance challenges of water reallocation have political and normative dimensions interwoven into more technical and design questions [57]. The EU Water Framework Directive, for example, sets significant environmental goals, which require water reallocation to be met; but, currently, it has had a limited implementation because of a lack of political will [61]. Water reallocation is also guided by normative principles; such as, efficiency, equity, and sustainability, which-at times_can be in conflict with each other [62]. For example, water reallocation can have the potential for efficiency gains in terms of overall net benefit to society but can simultaneously pose significant equity problems because the negatively affected actors are poor [63].

\subsection{Justifying and Presenting a SHR-WR Framework for Highly Modified River Basins}

As highlighted in the previous sections, research on human-natural systems and the related adaptive governance research, provides limited guidance for understanding and influencing complicated and context-dependent real-life governance situations $[36,44]$. The field also provides sparse direct links between governance processes and modifications in natural resource use $[45,46]$. Many of the existing frameworks are furthermore meant to cater for all water governance situations $[64,65]$ or all natural resource governance situations [66]. This, despite calls from researchers that frameworks need to find a balance between abstract design principles, which are insensitive to the setting, and an overemphasis on the empirical context, which limits the possibilities of drawing more generic conclusions $[44,66]$.

In response to the above challenges, our suggested framework, Figure 1, is a fitting innovation since it builds on SHR research and incorporates insight from water reallocation scholarship to complement our understanding of the governance of highly modified river basins. It furthermore establishes a clear link between governance processes and modified natural resource use and resilience shifts since the adaptive capacity of the socialhydrological system is defined as the capacity to reallocate water. The framework thus focuses on water reallocation as a key management option, which shifts absorptive capacity between the sub-systems in, or strongly related to, the river basin-in our case the electric system and riverine ecosystem. Our framework specifically identifies the absorptive capacity of the electric system as being dependent on flexibility and that of the riverine ecosystem as being dependent on connectivity. Finally, our proposed framework is specific to highly modified rivers and, thus, focus on a type of social-hydrological system that exists world-wide [2]. Consequently, it is of general interest, yet sufficiently specific to contribute 
to the construction of causal middle-range theories, and contextual generalizations that apply to a delimited set of cases [36,67-69].

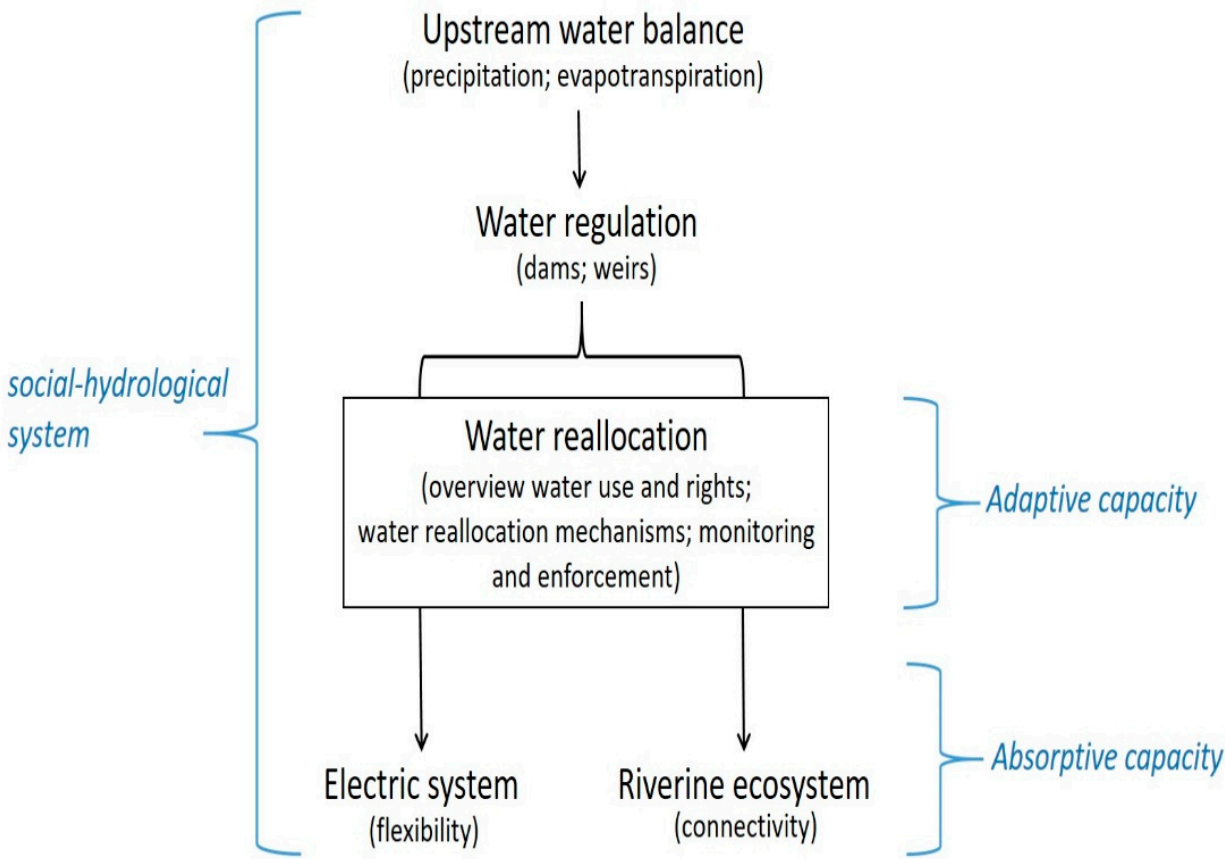

Figure 1. A framework of water reallocation and resilience in highly modified rivers.

\section{Testing the Framework with a Focus on Sweden}

Throughout the 20th century, Swedish rivers underwent significant modification, to expand hydropower production. Sweden is the biggest hydropower producer in the EU, with an average yearly production of 65 terawatt-hours (TWh) [33]. Roughly 2000 hydropower projects in Sweden satisfy around $40 \%$ of Sweden's total electricity demand [70]. In many ways, Sweden's water law, of 1918, favored the rapid expansion of hydropower production in the country, and formed the backbone of the Swedish judicial and administrative system, regulating hydropower, until 2019 [71]. The vast majority, roughly $90 \%$, of water allocation permits for hydropower production in Sweden was implemented under the 1918 water law [72]. A new water law came into force in 1983, and the Environmental Code introduced various new environmental considerations, in 1999; however, neither had any direct retroactive effect on existing hydropower permits. In fact, it was not until 2019, that legislation introduced by the Swedish Parliament came into effect, which set up a National Plan for Hydropower (NPH) permit review, in order to ensure that all existing hydropower projects possess permits with "modern environmental provision" [73]. Furthermore, the new legislation requires, as a general rule, that an operator carries out a permit review every 40 years, in order to ensure the continuous updating of environmental provisions.

We view the legislative changes of 2019 as a critical juncture point [74] in the governance of highly modified river basins in Sweden. We will therefore, in this section, undertake a structured analysis of the capacity for water reallocation, pre- and post-2019, in order to understand how changes in the Swedish governance system relate to highly modified rivers. The section starts with detailing how hydropower expansion in Sweden has affected the absorptive capacity of the electric system and various riverine ecosystems.

\subsection{Absorptive Capacity of the Riverine Eco-and Electric Systems in Sweden}

Seven out of eight large river systems, and nine out of 12 medium river systems, in Sweden suffer significant loss of connectivity. The main reasons for this are the river channel fragmentation and flow regulation that are caused by hydropower production [2,75]. Thus, connectivity loss—caused by hydropower expansion-significantly limits the absorptive 
capacity of a majority of riverine ecosystems in Sweden. At the same time, the high level of river modification, for hydropower production, gives the Swedish electric system significant flexibility [76]. Figure 2, below, shows how hydropower provides virtually all of the flexibility in the Swedish electric system, on an instantaneous and daily scale, as well as more than half of the flexibility on a yearly scale. Thus, the flexibility provided by hydropower production gives the Swedish electric system significant absorptive capacity over all timescales.

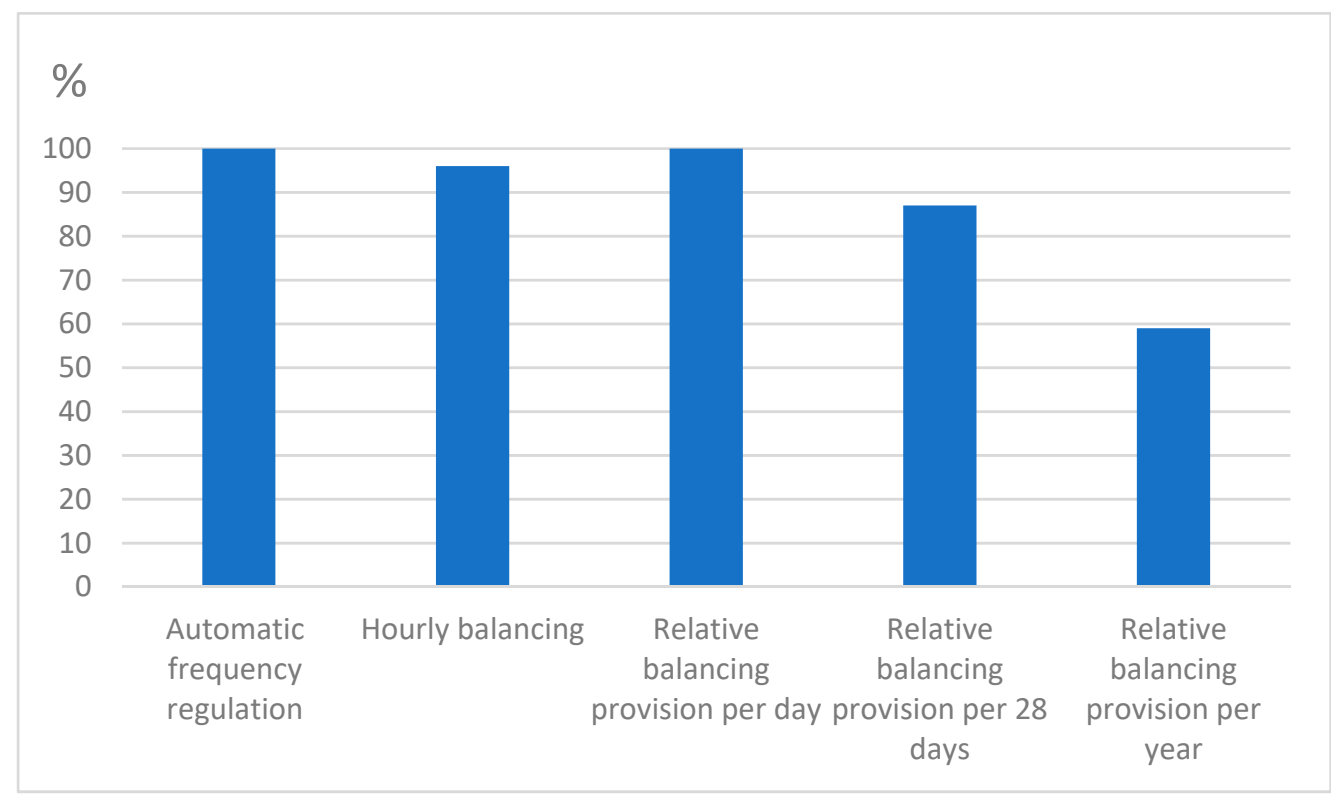

Figure 2. Hydropower's share of balancing services to the Swedish electric grid during the years 2008-2016, data source [76].

\subsection{Water Reallocation until 2019}

Only a limited overview is available of water abstraction and rights in Sweden, related to small hydropower production. In 2009, the Swedish County Administrative Boards $(\mathrm{CAB})$ reported that there were 1552 hydropower stations in Sweden, whereas an energy trade organization reported 1800 and a small hydropower trade organization 2101 [72]. This large discrepancy in the number of identified hydropower stations reflects a situation where only parts of existing hydropower projects possess permits for their operations. In particular, small-scale hydropower projects claim historic rights as the basis for their water allocation. Moreover, a complete registry of historic rights holders does not exist in Sweden and the validity, scope, and limits of such rights for hydropower production is contested [77].

Until 2019, existing reallocation mechanisms worked to preserve the initial allocation of water for hydropower production. The operating conditions that were stipulated in a hydropower permit, including the allocation of water flow into turbines for energy production, were granted without time limits and held legal force against all parties [78]. If a public agency initiated a permit review, the burden of proof was on them to provide the technical studies and documentation to persuade a court that any proposed water reallocation was technically feasible, reasonable, and did not impose conditions that significantly interfered with hydropower production. In addition, the responsible public authority was required to provide monetary compensation to the producer for losses, caused by water reallocation, which exceeded 5\% of the station's production value [79]. The result of such restrictive water reallocation mechanisms is demonstrated by the calculation that, between 1990 and 2010, the reallocation of water from hydropower to river restoration amounted to a mere $0.02 \%$ of the average yearly hydropower production [80]. 
The monitoring and enforcement of hydropower production is also limited by the fact that the conditions contained in most hydropower permits are difficult to interpret, and a significant number of hydropower stations lack permits altogether, since they claim historic rights as the basis for their original water allocation [81].

\subsection{Water Reallocation from 2019}

The overview of water abstraction and rights has been improved by the new legislation, as all existing hydropower installations are now required either to apply for a new permit or to sign up to the NPH [82]. The NPH was created by national agencies to organize and coordinate the permit review process on a national scale, over 20 years [76]. Hydropower installations that have valid claims to time-immemorial rights, as the basis for their operations, and that sign up to the NPH are treated as operators in possession of a permit for hydropower production [73]. The NPH introduces various new water reallocation mechanisms. When they sign up to the NPH, hydropower operators are required to apply for a permit review by a specific date that is established in the plan. The first hydropower permit review will be sent to the Swedish Land and Environmental Court by February 2022. Thereafter, the burden of proof, in the permit review process, falls on the hydropower operator and the prohibition against imposing conditions that significantly interfere with hydropower production no longer applies. The requirement for the public to provide compensation for losses exceeding $5 \%$ of the production value of the hydropower project is also phased out [73]. Once there is a firm ruling from the court, actual work begins at the concerned hydropower stations to reallocate water for river restoration, in line with the modern environmental provisions of the new permit, or to remove the installation and restore the river stretch if the hydropower permit is withdrawn. However, hydropower operators become eligible to receive compensation, which covers roughly $90 \%$ of all costs associated with the process. This includes administrative and construction costs as well as any loss in hydropower production caused by water reallocation [83]. The funding comes from a private fund, financed by eight of the biggest hydropower producers in Sweden. The fund designates EUR 50 million a year, during a 20-year period, for these measures. The creation of this fund was incentivized by a general tax reduction on hydropower installations worth EUR 190 million a year [84]. As guidance for the NPH, the Swedish Agency for Marine and Water Management (SwAM) and the Swedish Energy Agency (SEA) established a national strategy, which includes a planning limit on how great a loss water reallocation, for river restoration measures, should be allowed to cause. This amounts to a $2.3 \%$ loss of average annual hydropower production, equal to $1.5 \mathrm{TWh} /$ year [85]. At medium-scale installations, fish-passage facilities are envisioned, where water should be reallocated to provide $5 \%$ of the average river flow. It is estimated that the measures will reduce hydropower production by approximately $0.8 \mathrm{TWh} /$ year. It is envisioned that fish passages, with monthly low flows (MLQ), should be installed in all (approximately) 1700 small-scale hydropower installations ( $<10$ megawatt (MW) capacity). Complete water reallocation, i.e., the removal of hydropower installations altogether is also envisioned as a possibility for these installations. It is calculated that the water reallocation of small hydropower stations could lead to a loss of approximately $0.7 \mathrm{TWh} /$ year of hydropower production.

The NPH sets out how the largest installations in Sweden, approximately 140 in number and which produce roughly $65 \%$ of the country's total hydropower production, are intended to be exempt from water reallocation measures. These large hydropower stations divert water, causing dry riverbeds for distances exceeding $500 \mathrm{~m}$ and/or have dams that are higher than $50 \mathrm{~m}$ in height. The NPH's stated focus is to increase these stations' contribution to the overall flexibility of the electric system. Estimates suggest that an increase of $3900 \mathrm{MW}$ in hydropower's overall effect is achievable, by strategically increasing the capacity of specific hydropower stations, in order to remove bottlenecks in the cascading hydropower systems [86]. The NPH foresees that new permits for such capacity increasing measures will be examined and decided in parallel with the permit reviews. 
The monitoring and enforcement of hydropower operations continue to suffer from the existence of gaps in the available data concerning water abstraction in Sweden [87]. However, requiring all existing hydropower stations either to apply for a permit review or to sign up to the NPH will increase the amount of basic data available, which in turn could improve overview, monitoring, and enforcement. Additionally, by granting timeimmemorial rights the same legal status as a permit for hydropower production, monitoring and enforcement should be furthermore streamlined, because this goes some way towards resolving the questions concerning the validity of time-immemorial rights in hydropower production [77].

\subsection{Resilience Implications of Swedish Governance Modifications}

Sweden's large-scale hydropower expansion during the last century means that hydropower gives the electric system high flexibility and absorptive capacity, while significantly decreasing river connectivity and the absorptive capacity of riverine ecosystems in most rivers. Until 2019, the Swedish governance system exhibited a limited adaptive capacity as concerns highly modified rivers; as, essentially, it worked to maintain the status quo of hydropower production. Water allocation for hydropower production was granted through permits that had no time limit and which placed exceedingly high requirements on the public to justify water reallocation, to increase river connectivity.

The legislative and administrative changes of 2019 considerably increased the adaptive capacity of the governance system, by requiring operators to initiate a review every 40 years, to update the environmental provisions in the permit, and by modifying Swedish water reallocation mechanisms. However, in the current round of permit reviews, the increase in adaptive capacity mainly exists in small- and medium-sized hydropower stations, where the real scope for water reallocation has been created. The highest adaptive capacity exists for small hydropower stations, where there is even room for complete water reallocation, through dam removal. As Sweden's small hydropower stations are situated on small rivers and tributaries, it can be expected that these will exhibit the most significant increase in river connectivity in the coming years. Thus, important potential exists to increase the absorptive capacity of riverine ecosystems of small rivers and tributaries in Sweden, through water reallocation together with additional restoration measures [88]. Any negative impact on the absorptive capacity of the Swedish electric system, from such water reallocation will be limited. Small hydropower stations are run-of-river stations that constitute less than $1 \%$ of the installed capacity of hydropower production and which provide even less flexibility to the electric grid [89].

The governance modifications provide limited scope for water reallocation, to increase connectivity and the absorptive capacity of riverine ecosystems, in large Swedish river systems, with large hydropower stations. The modifications are intended to increase water allocation for hydropower production, by increasing hydropeaking, in order to increase the flexibility of hydropower production [76], thereby increasing the absorptive capacity of the electric system. Increased hydropeaking has documented negative effects on river connectivity [90] and can be expected to further decrease the absorptive capacity of the affected large riverine ecosystems.

\section{Discussion}

The proposed framework provides a means to compare Sweden's river governance, pre- and post-2019. Our initial analysis highlights how administrative and legal changes, implemented in 2019 and after, significantly modified existing water reallocation mechanisms and increased the Swedish governance system's adaptive capacity as concerns small and medium-sized, highly modified rivers. It also highlights the tradeoffs in the political bargaining process in Sweden, which underlies these governance modifications. Whereas water reallocation is facilitated for small-scale hydropower, to increase river connectivity and absorptive capacity in small rivers and tributaries, additional water allocation for largescale hydropower is encouraged in larger rivers, to increase flexibility and the absorptive 
capacity of the electric system. The flexibility provided by large hydropower production is thus deemed so valuable by policymakers that it is meant not to decrease, and even increase, which practically eliminates the scope for improvement of river connectivity in large highly modified rivers in Sweden.

An application of the framework should provide similar clarity of analysis and a possibility for the cross-case analysis of various other countries, which have a large number of highly modified rivers from hydropower production; including, China, Brazil, the USA, and Norway. This could also be of special relevance to an analysis of the EU's top hydropower producing countries (e.g., France, Austria, Spain, and Italy), which are subject to the same overarching EU legislation that requires improvements in freshwater connectivity, to improve riverine ecosystem functioning and resilience [61]. In all these countries, the framework directs us towards scrutinizing the extent to which water has been reallocated, to increase river connectivity.

As a second step, and in order to explain any possible differences between the countries, the framework provides a basis for explaining the extent of water reallocation through exploring causal mechanisms focused on governance [36,67]. The different countries' water reallocation mechanisms could be analyzed and compared, to understand why more or less water is reallocated to increase river connectivity. In the case of Sweden, the pre- and post-2019 comparative analysis provides a strong causal narrative, which supports the significant role that legislation plays in providing adaptive capacity to allow for water reallocation. Comparative analysis between Sweden and the USA provides further evidence to support this conclusion [80]. This insight is, furthermore, in line with research on adaptive water governance in the USA, which highlights the role of legal, procedural requirements in creating flexibility and adaptive capacity in water governance [91,92]. Understanding why the legislation looks the way it does, and why it occasionally undergoes significant modifications - as in Sweden, in 2019_-provides opportunities for yet another layer of causal analysis. In such analysis, institutions can be conceptualized as expressions of power to protect the interests of certain groups, and legislation, as the formally sanctioned rules to regulate conflict in situations in which interests cannot be harmonized [93]. Theories of the policy process, such as the Advocacy Coalition Framework, could then be used to analyze why and how legislation directing water governance undergoes important modification or remains unchanged [94].

Since we do not have a clear opinion about how SHR and its governance ought to change, we have not made transformation part of our framework, although this concept forms an integral part of resilience thinking [34]. However, we can discuss transformation and river basins, based on earlier political intentions and ongoing changes in societal preferences. The process of creating a highly modified river basin constitutes a transformation of the SH system, which-in the case of hydropower production-transforms river basins, from ecosystems to electric production systems. In Sweden, politicians actively supported this transformation, over the past decade, as significantly increased hydropower production was deemed positive and necessary for the development of the country [71]. With increasing attention being put on the biodiversity crisis, there is a normative shift, towards protecting and restoring aquatic biodiversity [12-14].

As concerns Sweden, we can already see clear signs that water reallocation will occur in smaller rivers and tributaries, whereas large-scaled rivers will enjoy limited water reallocation, or even increased water allocation to hydropower. Will this lead to a transformation of highly modified river basins and hydropower towards sustainability? We believe that a more suitable concept, to describe the ongoing changes in Sweden, is that of reconciliation: changes designed to help undo the negative ecological effects of regime shifts [95]. Although heavily modified rivers in Sweden will undergo restoration efforts, and in some smaller rivers and tributaries the water reallocation will be significant; overall, the majority of Swedish river flow is set to continue to function for the electric production system, with limited improvements in connectivity. 
Water abstraction for irrigation is the main focus of water reallocation research [31]. A weakness of our proposed framework is that it focuses on 'blue' water: the water present in streams and lakes, with limited attention given to 'green' water: soil moisture [65]. This makes our framework less suitable for analyzing rivers that have been highly modified, primarily for water abstraction for irrigation. Agriculture also represents an activity where system boundaries are more challenging to establish, because of the virtual flows of water embedded in the international food trade [96]. Thus, this paper's systemic approach, which was applied to analyzing water reallocation and resilience, will need modification to capture the main variables and processes relevant to highly modified river basins, where agricultural irrigation is the key challenge.

\section{Conclusions}

This article built on insights from social hydrological resilience and water reallocation research to create a framework for analyzing highly modified rivers. This framework established a clear link between governance processes, modified natural resource management and resilience shifts. Three governance variables were identified from the literature as crucial in determining capacity for water reallocation: having an overview of existing water use and rights, creating/maintaining cost effective and flexible mechanisms for water reallocation, and monitoring and enforcing the compliance of water use. We tested the framework using Sweden, a country with many heavily modified rivers due to hydropower production. Large-scaled dam hydropower increases the absorptive capacity of the electric system, because of its efficient frequency control that creates flexibility, while simultaneously decreasing river connectivity by causing fragmentation and artificial flows.

We conducted a structured analysis pre- and post- 2019, a critical year in Swedish river basin governance, because of legislative and administrative changes. We found these changes considerably increased the governance system's adaptive capacity, by requiring operators to initiate a review, every 40 years and due to modified water reallocation mechanisms. However, we determined the increase in adaptive capacity was relative, as the real scope for water reallocation existed only in small- and medium-sized hydropower stations and rivers. In large hydropower rivers, governance modifications are intended to increase the flexibility of hydropower production, thereby increasing the absorptive capacity of the electric system.

A further application of the framework should provide similar clarity of analysis and offer a possibility for cross-case analysis of various countries, with highly modified hydropower producing rivers. We believe our framework could contribute to the construction of middle-range theories to assist our understanding of why and how governance processes function, change, and use adaptive capacity to reallocate more or less water in highly modified rivers, with ensuing resilience shifts.

Author Contributions: Conceptualization, P.M.R.; investigation, P.M.R.; interpretation of data, P.M.R. and T.K.; writing—original draft preparation P.M.R.; writing—review and editing T.K. All authors have read and agreed to the published version of the manuscript.

Funding: This research received no external funding.

Data Availability Statement: Data sharing not applicable.

Acknowledgments: Kate Yeadon edited and improved the language of this article. We thank the anonymous reviewers for their comments on earlier versions of the manuscript.

Conflicts of Interest: The authors declare no conflict of interest.

\section{References}

1. Vörösmarty, C.J.; McIntyre, P.B.; Gessner, M.O.; Dudgeon, D.; Prusevich, A.; Green, P.; Glidden, S.; Bunn, S.E.; Sullivan, C.A.; Liermann, C.R.; et al. Global Threats to Human Water Security and River Biodiversity. Nature 2010, 467, 555-561. [CrossRef] [PubMed] 
2. Grill, G.; Lehner, B.; Thieme, M.; Geenen, B.; Tickner, D.; Antonelli, F.; Babu, S.; Borrelli, P.; Cheng, L.; Crochetiere, H.; et al. Mapping the World's Free-Flowing Rivers. Nature 2019, 569, 215-221. [CrossRef] [PubMed]

3. Poff, N.L.; Allan, J.D.; Bain, M.B.; Karr, J.R.; Prestegaard, K.L.; Richter, B.D.; Sparks, R.E.; Stromberg, J.C. The Natural Flow Regime. BioScience 1997, 47, 769-784. [CrossRef]

4. Bunn, S.E.; Arthington, A.H. Basic Principles and Ecological Consequences of Altered Flow Regimes for Aquatic Biodiversity. Environ. Manag. 2002, 30, 492-507. [CrossRef]

5. Reid, A.J.; Carlson, A.K.; Creed, I.F.; Eliason, E.J.; Gell, P.A.; Johnson, P.T.J.; Kidd, K.A.; MacCormack, T.J.; Olden, J.D.; Ormerod, S.J.; et al. Emerging Threats and Persistent Conservation Challenges for Freshwater Biodiversity. Biol. Rev. 2019, 94, 849-873. [CrossRef] [PubMed]

6. Poff, N.L.; Zimmerman, J.K.H. Ecological Responses to Altered Flow Regimes: A Literature Review to Inform the Science and Management of Environmental Flows. Freshw. Biol. 2010, 55, 194-205. [CrossRef]

7. Poff, N.L.; Richter, B.D.; Arthington, A.H.; Bunn, S.E.; Naiman, R.; Kendy, E.; Acreman, M.; Apse, C.; Bledsoe, B.P.; Freeman, M.C.; et al. The Ecological Limits of Hydrologic Alteration (ELOHA): A New Framework for Developing Regional Environmental Flow Standards. Freshw. Biol. 2010, 55, 147-170. [CrossRef]

8. Peterson, G.; Allen, C.R.; Holling, C.S. Ecological Resilience, Biodiversity, and Scale. Ecosystems 1998, 1, 6-18. [CrossRef]

9. De Leo, G.A.; Levin, S. The Multifaceted Aspects of Ecosystem Integrity. Conserv. Ecol. 1997, 1, 3. [CrossRef]

10. Dudgeon, D. Multiple Threats Imperil Freshwater Biodiversity in the Anthropocene. Curr. Biol. 2019, 29, R960-R967. [CrossRef]

11. Walker, B.H. Biodiversity and Ecological Redundancy. Conserv. Biol. 1992, 6, 18-23. [CrossRef]

12. Tickner, D.; Opperman, J.J.; Abell, R.; Acreman, M.; Arthington, A.H.; Bunn, S.E.; Cooke, S.J.; Dalton, J.; Darwall, W.; Edwards, G.; et al. Bending the Curve of Global Freshwater Biodiversity Loss: An Emergency Recovery Plan. BioScience 2020, 70, 330-342. [CrossRef] [PubMed]

13. European Commission. EU Biodiversity Strategy for 2030 Bringing Nature Back into Our Lives Brussels, 20.5.2020 COM(2020) 380 Final; European Commission: Brussels, Belgium, 2020.

14. Hirsch, T.; Mooney, K.; Cooper, D.; Maruma Mrema, E. Global Biodiversity Outlook 5; Secretariat of the Convention on Biological Diversity: Montreal, QC, Canada, 2020.

15. Richter, B.D.; Andrews, S.; Dahlinghaus, R.; Freckmann, G.; Ganis, S.; Green, J.; Hardman, I.; Palmer, M.; Shalvey, J. Buy Me a River: Purchasing Water Rights to Restore River Flows in the Western USA. JAWRA J. Am. Water Resour. Assoc. 2020, 56, 1-15. [CrossRef]

16. Marston, L.; Cai, X. An Overview of Water Reallocation and the Barriers to Its Implementation. WIREs Water 2016, 3, 658-677. [CrossRef]

17. Johnson, S.E.; Graber, B.E. Enlisting the Social Sciences in Decisions about Dam Removal: The Application of Social Science Concepts and Principles to Public Decisionmaking about Whether to Keep or Remove Dams May Help Achieve Outcomes Leading to Sustainable Ecosystems and Other Goals in the Public Interest. BioScience 2002, 52, 731-738. [CrossRef]

18. Energimyndigheten Värdebeskrivning Lule Älv [Description of Lule River's Values]; Unpublished Report; Swedish Energy Agency: Eskilstuna, Sweden, 2018.

19. Sparrevik, E.; Viklands, H.; Bergsten, P.; Harju, L. Ekologiska Effekter Och Verksamhetspåverkan Av Förändrade Produktionsvillkor i Vattenfalls Storskaliga Vattenkraftverk [Ecological Effects and Business Impacts from Changed Production Provisions in Vattenfall's Large Scale Hydropower Instalations]. Vattenfall Power Consultant AB. 2011. Available online: https://docplayer.se/16485922 -Ekologiska-effekter-och-verksamhetspaverkan-av-forandrade-produktionsvillkor-i-vattenfalls-storskaliga-vattenkraftverk.html (accessed on 25 September 2021).

20. Baird, J.; Plummer, R. Water Resilience: Management and Governance in Times of Change; Springer Nature: Cham, Switzerland, 2021; ISBN 978-3-030-48110-0.

21. Rodina, L. Defining “Water Resilience": Debates, Concepts, Approaches, and Gaps. WIREs Water 2019, 6, e1334. [CrossRef]

22. Troy, T.J.; Pavao-Zuckerman, M.; Evans, T.P. Debates-Perspectives on Socio-Hydrology: Socio-Hydrologic Modeling: Tradeoffs, Hypothesis Testing, and Validation. Water Resour. Res. 2015, 51, 4806-4814. [CrossRef]

23. Mao, F.; Clark, J.; Karpouzoglou, T.; Dewulf, A.; Buytaert, W.; Hannah, D. HESS Opinions: A Conceptual Framework for Assessing Socio-Hydrological Resilience under Change. Hydrol. Earth Syst. Sci. 2017, 21, 3655-3670. [CrossRef]

24. Dewulf, A.; Karpouzoglou, T.; Warner, J.; Wesselink, A.; Mao, F.; Vos, J.; Tamas, P.; Groot, A.E.; Heijmans, A.; Ahmed, F.; et al. The Power to Define Resilience in Social-Hydrological Systems: Toward a Power-Sensitive Resilience Framework. WIREs Water 2019, 6, e1377. [CrossRef]

25. Jager, H.I.; Smith, B.T. Sustainable Reservoir Operation: Can We Generate Hydropower and Preserve Ecosystem Values? River Res. Appl. 2008, 24, 340-352. [CrossRef]

26. Barbour, E.J.; Holz, L.; Kuczera, G.; Pollino, C.A.; Jakeman, A.J.; Loucks, D.P. Optimisation as a Process for Understanding and Managing River Ecosystems. Environ. Model. Softw. 2016, 83, 167-178. [CrossRef]

27. O'Hanley, J.R.; Pompeu, P.S.; Louzada, M.; Zambaldi, L.P.; Kemp, P.S. Optimizing Hydropower Dam Location and Removal in the São Francisco River Basin, Brazil to Balance Hydropower and River Biodiversity Tradeoffs. Landsc. Urban Plan. 2020, 195, 103725. [CrossRef]

28. Di Baldassarre, G.; Viglione, A.; Carr, G.; Kuil, L.; Yan, K.; Brandimarte, L.; Blöschl, G. Debates—Perspectives on Socio-Hydrology: Capturing Feedbacks between Physical and Social Processes. Water Resour. Res. 2015, 51, 4770-4781. [CrossRef] 
29. Horne, A.; Szemis, J.M.; Kaur, S.; Webb, J.A.; Stewardson, M.J.; Costa, A.; Boland, N. Optimization Tools for Environmental Water Decisions: A Review of Strengths, Weaknesses, and Opportunities to Improve Adoption. Environ. Model. Softw. 2016, 84, 326-338. [CrossRef]

30. Rudberg, P.M.; Smits, M. Learning-Based Intervention for River Restoration. Ecol. Soc. 2018, 23, 13. [CrossRef]

31. Grafton, R.Q.; Garrick, D.; Horne, J. Water Misallocation: Governance Challenges and Responses; World Bank: Washington, DC, USA, 2017.

32. Cosens, B.A.; Stow, C.A. Resilience and water governance: Addressing fragmentation and uncertainty in water allocation and water quality law. In Social-Ecological Resilience and Law; Garmestani, A.S., Allen, C.R., Eds.; Columbia University Press: New York, NY, USA, 2014.

33. Eurostat. Gross Electricity Generation Main Activity Electricity Only_Hydro 2018; Eurostat: Luxembourg, 2018.

34. Folke, C.; Carpenter, S.R.; Walker, B.; Scheffer, M.; Chapin, T.; Rockström, J. Resilience Thinking: Integrating Resilience, Adaptability and Transformability. Ecol. Soc. 2010, 15, 20. [CrossRef]

35. Olsson, L.; Jerneck, A.; Thoren, H.; Persson, J.; O’Byrne, D. Why Resilience Is Unappealing to Social Science: Theoretical and Empirical Investigations of the Scientific Use of Resilience. Sci. Adv. 2015, 1, e1400217. [CrossRef]

36. Biesbroek, R.; Dupuis, J.; Wellstead, A. Explaining through Causal Mechanisms: Resilience and Governance of Social-Ecological Systems. Sustain. Gov. 2017, 28, 64-70. [CrossRef]

37. Holling, C.S. Resilience and Stability of Ecological Systems. Annu. Rev. Ecol. Syst. 1973, 4, 1-23. [CrossRef]

38. Plummer, R.; Armitage, D. Integrating perspectives on adaptive capacity and environmental governance. In Adaptive Capacity and Environmental Governance; Springer: Berlin/Heidelberg, Germany, 2010; pp. 1-19.

39. Karpouzoglou, T.; Dewulf, A.; Clark, J. Advancing Adaptive Governance of Social-Ecological Systems through Theoretical Multiplicity. Environ. Sci. Policy 2016, 57, 1-9. [CrossRef]

40. Hasselman, L. Adaptive Management; Adaptive Co-Management; Adaptive Governance: What's the Difference? Australas. J. Environ. Manag. 2017, 24, 31-46. [CrossRef]

41. Hill Clarvis, M.; Allan, A.; Hannah, D.M. Water, Resilience and the Law: From General Concepts and Governance Design Principles to Actionable Mechanisms. Environ. Sci. Policy 2014, 43, 98-110. [CrossRef]

42. Hurlbert, M.A.; Diaz, H. Water Governance in Chile and Canada. Ecol. Soc. 2013, 18, 61. [CrossRef]

43. Cosens, B.; Gunderson, L. Practical Panarchy for Adaptive Water Governance: Linking Law to Social-Ecological Resilience; Springer: Berlin/Heidelberg, Germany, 2018; ISBN 3-319-72472-X.

44. Sharma-Wallace, L.; Velarde, S.J.; Wreford, A. Adaptive Governance Good Practice: Show Me the Evidence! J. Environ. Manag. 2018, 222, 174-184. [CrossRef] [PubMed]

45. Suškevičs, M.; Hahn, T.; Rodela, R.; Macura, B.; Pahl-Wostl, C. Learning for Social-Ecological Change: A Qualitative Review of Outcomes across Empirical Literature in Natural Resource Management. J. Environ. Plan. Manag. 2018, 61, 1085-1112. [CrossRef]

46. De Kraker, J. Social Learning for Resilience in Social-Ecological Systems. Curr. Opin. Environ. Sustain. 2017, $28,100-107$. [CrossRef]

47. Dehghanian, P.; Aslan, S.; Dehghanian, P. Maintaining Electric System Safety Through An Enhanced Network Resilience. IEEE Trans. Ind. Appl. 2018, 54, 4927-4937. [CrossRef]

48. Bie, Z.; Lin, Y.; Li, G.; Li, F. Battling the Extreme: A Study on the Power System Resilience. Proc. IEEE 2017, 105, 1253-1266. [CrossRef]

49. Phillips, T.; Chalishazar, V.; McJunkin, T.; Maharjan, M.; Alam, S.M.S.; Mosier, T.; Somani, A. A Metric Framework for Evaluating the Resilience Contribution of Hydropower to the Grid. In Proceedings of the 2020 Resilience Week (RWS), Salt Lake City, UT, USA, 19-23 October 2020; pp. 78-85.

50. Côté, I.M.; Darling, E.S. Rethinking Ecosystem Resilience in the Face of Climate Change. PLOS Biol. 2010, 8, e1000438. [CrossRef] [PubMed]

51. McManamay, R.A.; Brewer, S.K.; Jager, H.I.; Troia, M.J. Organizing Environmental Flow Frameworks to Meet Hydropower Mitigation Needs. Environ. Manag. 2016, 58, 365-385. [CrossRef]

52. Bejarano, M.D.; Sordo-Ward, A.; Gabriel-Martin, I.; Garrote, L. Tradeoff between Economic and Environmental Costs and Benefits of Hydropower Production at Run-of-River-Diversion Schemes under Different Environmental Flows Scenarios. J. Hydrol. 2019, 572, 790-804. [CrossRef]

53. Meinzen-Dick, R.; Ringler, C. Water Reallocation: Drivers, Challenges, Threats, and Solutions for the Poor. J. Hum. Dev. 2008, 9 47-64. [CrossRef]

54. Liu, H.; Cai, X.; Geng, L.; Zhong, H. Restoration of Pastureland Ecosystems: Case Study of Western Inner Mongolia. J. Water Resour. Plan. Manag. 2005, 131, 420-430. [CrossRef]

55. Dadson, S.J.; Garrick, D.E.; Penning-Rowsell, E.C.; Hall, J.W.; Hope, R.; Hughes, J. Water Science, Policy and Management: A Global Challenge; John Wiley \& Sons: Hoboken, NJ, USA, 2020; ISBN 1-119-52060-6.

56. Pease, M. Constraints to Water Transfers in Unadjudicated Basins: The Middle Rio Grande as a Case Study. J. Contemp. Water Res. Educ. 2010, 144, 37-43. [CrossRef]

57. Hellegers, P.; Leflaive, X. Water Allocation Reform: What Makes It so Difficult? Water Int. 2015, 40, 273-285. [CrossRef]

58. Speed, R.; Yuanyuan, L.; Zhiwei, Z.; Le Quesne, T.; Pegram, G. Basin Water Allocation Planning: Principles, Procedures and Approaches for Basin Allocation Planning; UNESCO: Paris, France, 2013. 
59. Loch, A.; Pérez-Blanco, C.D.; Carmody, E.; Felbab-Brown, V.; Adamson, D.; Seidl, C. Grand Theft Water and the Calculus of Compliance. Nat. Sustain. 2020, 3, 1012-1018. [CrossRef]

60. Mezger, G.; De Stefano, L.; González del Tánago, M. Assessing the Establishment and Implementation of Environmental Flows in Spain. Environ. Manag. 2019, 64, 721-735. [CrossRef] [PubMed]

61. European Commission. Commission Staff Working Document Fitness Check of the Water Framework Directive, Groundwater Directive, Environmental Quality Standards Directive and Floods Directive; Brussels, 10.12.2019, SWD(2019) 439 Final; European Commission: Brussels, Belgium, 2019.

62. WWAP. Managing Water under Uncertainty and Risk, The United Nations World Water Development Report 4, UN Water Reports, World Water Assessment Programme; UNESCO: Paris, France, 2012.

63. Kadigi, R.M.J.; Mdoe, N.S.Y.; Ashimogo, G.C.; Morardet, S. Water for Irrigation or Hydropower Generation?-Complex Questions Regarding Water Allocation in Tanzania. Agric. Water Manag. 2008, 95, 984-992. [CrossRef]

64. Pahl-Wostl, C.; Knieper, C.; Lukat, E.; Meergans, F.; Schoderer, M.; Schütze, N.; Schweigatz, D.; Dombrowsky, I.; Lenschow, A.; Stein, U.; et al. Enhancing the Capacity of Water Governance to Deal with Complex Management Challenges: A Framework of Analysis. Environ. Sci. Policy 2020, 107, 23-35. [CrossRef]

65. Falkenmark, M.; Wang-Erlandsson, L.; Rockström, J. Understanding of Water Resilience in the Anthropocene. J. Hydrol. X 2019, 2, 100009. [CrossRef]

66. Wyborn, C. Co-Productive Governance: A Relational Framework for Adaptive Governance. Glob. Environ. Change 2015, 30, 56-67. [CrossRef]

67. Hedström, P.; Ylikoski, P. Causal Mechanisms in the Social Sciences. Annu. Rev. Sociol. 2010, 36, 49-67. [CrossRef]

68. Ylikoski, P. Mechanism-Based Theorizing and Generalization from Case Studies. Stud. Hist. Philos. Sci. Part A 2019, 78, 14-22. [CrossRef] [PubMed]

69. Schlüter, M.; Orach, K.; Lindkvist, E.; Martin, R.; Wijermans, N.; Bodin, Ö.; Boonstra, W.J. Toward a Methodology for Explaining and Theorizing about Social-Ecological Phenomena. Curr. Opin. Environ. Sustain. 2019, 39, 44-53. [CrossRef]

70. Energiföretagen Vattenkraftsproduktion-Energiföretagen Sverige [Hydropower Production—Energy Companies Sweden] Available online: https://www.energiforetagen.se/energifakta/elsystemet/produktion/vattenkraft/vattenkraftsproduktion/ (accessed on 26 April 2021).

71. Vedung, E.; Brandel, M. Vattenkraften, Staten och de Politiska Partierna [Hydropower, the State and the Political Parties]; Nya Doxa: Nora, Sweden, 2001.

72. Statens Offentliga Utredningar. Vattenverksamhet, Delbetänkande Av Miljöprocessutredningen [Water Works, Partial Conclusions from the Environmental Processes Investigation], SOU 2009:42; Swedish Government Committee: Stockholm, Sweden, 2009.

73. Civilutskottet. Civilutskottets Betänkande 2017/18:CU31 Vattenmiliö Och Vattenkraft m.m. [The Committee of Civil Affairs' Decision on Water Environment and Hydropower etc.]; Swedish Parliament Committee of Civil Affairs: Stockholm, Sweden, 2017.

74. Falleti, T.G.; Lynch, J.F. Context and Causal Mechanisms in Political Analysis. Comp. Polit. Stud. 2009, 42, 1143-1166. [CrossRef]

75. Dynesius, M.; Nilsson, C. Fragmentation and Flow Regulation of River Systems in the Northern Third of the World. Science 1994, 266, 753. [CrossRef] [PubMed]

76. HaV. Förslag till Nationell Plan För Omprövning Av Vattenkraft [Proposed National Plan for Hydropower Permit Reviews]; Swedish Agency for Marine and Water Management: Gothenburg, Sweden, 2019.

77. Olsen Lundh, C. Tvenne Gånger Tvenne Ruttna Gärdesgårdar. Om Urminnes Hävd Och Vattenkraft [Twice Times Twice Rotting Farms. About Time Immemorial Rights and Hydropower]. Nord. Miljörättslig Tidskr. 2003, 2, 85-108.

78. Rudberg, P.M. Sweden's Evolving Hydropower Sector: Renovation, Restoration and Concession Change; Stockholm Environment Institute: Stockholm, Sweden, 2013.

79. Rudberg, P.M. Constant Concessions under Changing Circumstances: The Water and Renewable Energy Directives and Hydropower in Sweden; Stockholm Environment Institute: Stockholm, Sweden, 2011.

80. Rudberg, P.M.; Escobar, M.; Gantenbein, J.; Niiro, N. Mitigating the Adverse Effects of Hydropower Projects: A Comparative Review of River Restoration and Hydropower Regulation in Sweden and the United States. Georget. Int. Environ. Law Rev. 2015, 27,251 .

81. Miljösamverkan. Tillsyn Av Vattenkraftens Egenkontroll Ett Handläggarstöd [Supervision of Hydropower Owners' Control, Support for Administrators]; Miljösamverkan Sverige: Gothenburg, Sweden, 2012.

82. Miljöbalken Swedish Environmental Code 11 Chap, 27 §; Vol. 1998:808. Swedish Code of Statutes. Available online: https: //www.riksdagen.se/sv/dokument-lagar/dokument/svensk-forfattningssamling/miljobalk-1998808_sfs-1998-808 (accessed on 25 September 2021).

83. Vattenkraftens miljöfond. ALLMÄNNA VILLKOR För Finansiering via Vattenkraftens Miljöfond Sverige AB Reviderade 2020-09-08 [General Terms for Financing from Hydropower's Environmental Fund Sweden. Revised 2020-09-08]; Hydropower's Environmental Fund Sweden: Gothenburg, Sweden, 2020.

84. Finansdepartementet. Lagrådsremiss: Skatteförslag Med Anledning Av Energiöverenskommelsen [Council of Legislation Referral: Tax Proposal Related to the Energy Agreement]; Ministry of Finance: Stockholm, Sweden, 2017.

85. Energimyndigheten. Nationell Strategi För Hållbar Vattenkraft [National Strategy for Sustainable Hydropower]; Swedish Energy Agency: Eskilstuna, Sweden, 2014. 
86. SWECO. En Kvantitativ Analys Av Potentialen För Effektutbyggnad i Befintliga Svenska Vattenkraftverk [A Quantitative Analysis of the Potential for Increased Effect in Existing Swedish Hydropower Stations] UPPDRAGSNUMMER 5472418000; SWECO: Stockholm, Sweden, 2016.

87. SMHI. Ökad Kunskap Om Vattenuttag i Sverige Rapportering Av Regeringsuppdrag [Increased Knowledge of Water Abstraction in Sweden, Report on Government Task] HYDROLOGI Nr 126; Swedish Meteorological and Hydrological Institute: Norrköping, Sweden, 2020.

88. Miller, S.W.; Budy, P.; Schmidt, J.C. Quantifying Macroinvertebrate Responses to In-Stream Habitat Restoration: Applications of Meta-Analysis to River Restoration. Restor. Ecol. 2010, 18, 8-19. [CrossRef]

89. Energimyndigheten. Vattenkraftens Reglerbidrag Och Värde För Elsystemet [Hydropower's Share of Regulation and Value for the Electric System] ER 2016:11; Swedish Energy Agency: Eskilstuna, Sweden, 2016.

90. Bejarano, M.D.; Jansson, R.; Nilsson, C. The Effects of Hydropeaking on Riverine Plants: A Review. Biol. Rev. 2018, 93, 658-673. [CrossRef] [PubMed]

91. Craig, R.K.; Garmestani, A.S.; Allen, C.R.; Arnold, C.A.T.; Birgé, H.; DeCaro, D.A.; Fremier, A.K.; Gosnell, H.; Schlager, E. Balancing Stability and Flexibility in Adaptive Governance: An Analysis of Tools Available in U.S. Environmental Law. Ecol. Soc. J. Integr. Sci. Resil. Sustain. 2017, 22, 3. [CrossRef] [PubMed]

92. DeCaro, D.A.; Chaffin, B.C.; Schlager, E.; Garmestani, A.S.; Ruhl, J.B. Legal and Institutional Foundations of Adaptive Environmental Governance. Ecol. Soc. J. Integr. Sci. Resil. Sustain. 2017, 22, 32. [CrossRef] [PubMed]

93. Vatn, A. Institutions and the Environment Edward Elgar; Edward Elgar: Cheltenham, UK, 2005.

94. Sabatier, P.A.; Weible, C.M. Theories of the Policy Process; Westview Press: Boulder, CO, USA, 2014; ISBN 0-8133-4927-3.

95. Cosens, B.; Gunderson, L. Adaptive Governance in North American Water Systems: A Legal Perspective on Resilience and Reconciliation. In Water Resilience Management and Governance in Times of Change; Baird, J., Plummer, R., Eds.; Springer: Cham, Switzerland, 2021; ISBN 3-030-48110-7.

96. Rosa, L.; Chiarelli, D.D.; Tu, C.; Rulli, M.C.; D’Odorico, P. Global Unsustainable Virtual Water Flows in Agricultural Trade. Environ. Res. Lett. 2019, 14, 114001. [CrossRef] 